\title{
ZAUFANIE KLIENTA JAKO KLUCZOWY CZYNNIK BUDOWY WARTOŚCI PRZEDSIĘBIORSTW HANDLU DETALICZNEGO TYPU DIY
}

Z a r y s t r e ś c i: Przedmiotem rozważań w niniejszym opracowaniu jest zaufanie klienta i jego wpływ na kreowanie wartości dostarczanych przez przedsiębiorstwa handlowe nabywcom materiałów budowlanych.. Badania wykazały, że relacje partnerskie pomiędzy klientami i przedsiębiorstwami w procesie współtworzenia wartości muszą być budowane na zaangażowaniu stron. Dowiedziono, iż zaufanie w turbulentnym otoczeniu jest ważnym czynnikiem wpływającym na sukces rynkowy sieci DIY.

S ł o w a k 1 u c z o w e: zaufanie; klient; wartość przedsiębiorstwa; DIY.

Klasyfikacja JEL: L21; L22.

\section{WSTĘP}

W dynamicznie zmieniającym się otoczeniu rynkowym osiągnięcie trwałego sukcesu przez przedsiębiorstwa, w tym także sieci marketów budowlanych, jest zadaniem karkołomnym. Szybki rozwój sektora sprzedaży materiałów budowlanych i dekoracyjnych powoduje, że sieciom DIY coraz trudniej jest osiągnąc trwałą przewagę konkurencyjną [Zupok, 2014,

* Adres do korespondencji: Sebastian Zupok, Wyższa Szkoła Przedsiębiorczości i Marketingu w Chrzanowie, Wydział Społeczno-Gospodarczy, ul. J. Woynarowskiej 1, 32-500 Chrzanów, e-mail: sebastian.zupok_xl@wp.pl 
s. 61-62]. Współcześnie zarządzanie przedsiębiorstwem wymaga długookresowej perspektywy w dążeniu do zapewnienia wpływów oraz zysków. Rosnąca ilość produktów i konkurentów, wyrównany poziom cen, a także rosnące wymagania klientów sprawiają, że przedsiębiorstwo musi stać się partnerem klienta. Jeśli oczekuje od niego zaangażowania, samo powinno się zaangażować. Zrozumienie procesu budowania zaufania to zrozumienie układów partnerskich w relacjach klient-organizacja.

Wpływ zaufania klientów na wzrost wartości przedsiębiorstwa jest w dużym stopniu niedoceniany przez menadżerów. Obecnie w literaturze i coraz częściej w praktyce potwierdza się teza, że zaufanie prowadzi do wyartykułowania przez klientów swoich potrzeb, preferencji oraz doświadczeń. Wskazuje się również, że zaufanie jest podstawą inwestycji klienta w przedsiębiorstwo, w postaci informacji, emocji i czasu [Dobiegała-Korona, 2007, s. 18-24].

Niniejszy artykuł to próba zwrócenia uwagi na znaczenie zaufania aktualnych i potencjalnych klientów dla budowania wartości w warunkach coraz bardziej współzależnego otoczenia. Realizacja założonego celu była możliwa dzięki zastosowaniu metody analizy krytycznej źródeł literaturowych krajowych i zagranicznych dotyczących zaufania konsumenckiego. W opracowaniu przytoczono również wybrane wyniki badań własnych dających pewien pogląd na analizowaną problematykę [zob. także: Zupok, 2014].

\section{ISTOTA ZAUFANIA}

Dyskusyjnym problemem, który należy wyjaśnić jest bez wątpienia interpretacja pojęcia zaufania. Jest rzeczą znamienną, że różni autorzy posługują się tym terminem, przypisując mu różną treść. W literaturze spotkać można wiele prób zdefiniowania tego pojęcia, które dowodzą istnienia znacznej różnorodności poglądów oraz stanowisk. W istniejących definicjach najczęściej eksponowany jest aspekt socjologiczny oraz psychologiczny, a także ekonomiczny. Poza wymienionymi zasadniczymi podejściami, należy wyodrębnić kolejną grupę definicji cechujących się znacznym uogólnieniem, a nawet hasłowością. Sugerują one nieograniczoną swobodę interpretacji zaufania.

Zaufanie najczęściej kojarzone jest z otwartością, uczciwością, wiarygodnością, czy też życzliwością. Na przykład A. Giddens uważa, że zaufanie „to wiara w innych ludzi albo instytucje” [Giddens, 2006, s. 698]. Autor 
tej definicji dowodzi, że obecnie wyczerpują się tradycyjne formy zaufania. Znaczenia nabiera zaufanie do ludzi i organizacji nieznanych nam osobiście. Zaufanie oznacza wiarę w systemy abstrakcyjne. Według P. Sztompki zaufanie jest swego rodzaju zakładem podejmowanym na temat niepewnych, przyszłych, działań innych ludzi. Z kolei nieufność jest lustrzanym odbiciem zaufania [Sztompka, 2007, s. 69-70]. P. Dasgupta przedstawia następującą propozycję definicji: „zaufanie [...] to prawidłowe przewidywanie działań innych ludzi, które mają wpływ na działania jednostki w sytuacji, gdy wybór działania musi zostać dokonany, zanim możliwe będzie zaobserwowanie działań innych osób" [Sztompka, 2007, s. 71]. Zdaniem B. Notebooma zaufanie polega na chęci do podejmowania ryzyka, że mogą nas zawieźć inni, razem z oczekiwaniem, że nie uczynią tego, lub brakiem świadomości co do możliwości, że mogą to zrobić [Bylok, 2012, s. 96]. Zaufanie, jak twierdzi S. D. Boon i J. G. Holmes, to stan polegający na pewnych pozytywnych oczekiwaniach, co do czyichś motywów w odniesieniu do swojej osoby w sytuacjach, w których istnieje określone ryzyko [Boon, Holmes, 1991, s. 194].

Analiza literatury przedmiotu, poza wyżej wymienionym ujęciem pozwala wyodrębnić grupę definicji akcentujących wymiar ekonomiczny. I tak zdaniem F. Fukuyamy, dobrobyt kraju zależy od poziomu zaufania w społeczeństwie. Zauważa on dalej, że występują społeczeństwa o niskim i wysokim poziomie zaufania [Fukuyama, 1997, s. 44-45]. Zaufanie zatem ma wartość pragmatyczną - jako nieformalna norma redukuje koszty ekonomicznej transakcji [Inglehart, 1997]. Podobne poglądy prezentuje D. C. North. Ten amerykański laureat Nagrody Nobla rozpoznaje przyczyny niedorozwoju krajów Trzeciego Świata w niezdolności tamtejszych społeczeństw do stworzenia warunków obniżających koszty transakcji [Zak, Knack, 2001]. Należy podkreślić, że proces zaufania jest konsekwencją aktu woli człowieka. Niewątpliwie organizacje muszą kreować zaufanie do wysoko opłacalnych klientów, którzy mogą być najlepszym źródłem i gwarancją realizowania oczekiwanych zysków w przyszłości [na temat najcenniejszego kapitału przedsiębiorstwa - klienta, który dostarcza wartości patrz np. Dobiegała-Korona, 2006, s. 85-99]. L. Bruni i R. Sugden akcentują wpływ zaufania na kształt i przebieg stosunków międzyludzkich, w tym stosunków wymiany rynkowej, które są oparte w dużej mierze na zaufaniu. Na potwierdzenie przytaczają wyniki swoich badań. Ujawniają one, że rynek nie funkcjonowałby bez zaufania [Bruni, Sugden, 2000, s. 21]. Ważne podejście, z punktu widzenia tematu artykułu, prezentuje M. Neumann. Zaufanie między konsumentami a producentami, nazywa 
on, zaufaniem konsumenckim, rozumianym jako pozytywne nastawienie klientów do firmy oraz wynikiem postrzegania cech, na których ono bazuje [Neumann, 2006, s. 35]. Te najważniejsze cechy to podejście i nastawienie kierowników (szerzej: całego przedsiębiorstwa) do klienta. L. Young i G. Albaum, w wyniku przeprowadzonych badań empirycznych, stwierdzają, że wpływ na kreowanie zaufania mają zmienne osobowe i zmienne zachowania kierowników oraz personelu pracowniczego [Young, Albaum, 2003, s. 253-269]. Warto także nadmienić, że zaufanie należy rozpatrywać $\mathrm{z}$ punktu widzenia danej organizacji ( $\mathrm{tj}$. zaufanie intra-organizacyjne); zaufania pomiędzy organizacjami (tj. zaufania inter-organizacyjnego) nawiązującego do organizacji rozszerzonej (extended enterprise) oraz wirtualnej, a także zaufania człowiek - organizacja i organizacja - człowiek. Współcześnie podkreśla się znaczenie zaufania w obszarze governance, które obejmuje nie tylko troskę o maksymalizację wartości dla właścicieli oraz klientów, ale również respekt dla pracowników i interesariuszy organizacji. Ciekawe podejście prezentuje także W. M. Grudzewski oraz I. K. Hejduk. Według nich zaufanie opisywane jest poprzez koncepcje wielowymiarowe. Do pięciu głównych wymiarów zaufania zalicza się: wymiar osobowościowy, wymiar kalkulacyjny, wymiar instytucjonalny, wymiar percepcyjny oraz wymiar kumulacyjny [Grudzewski, Hejduk, 2007, s. 11-12].

Reasumując dotychczasowe rozważania, należy podkreślić, że zaufanie w literaturze jest interpretowane najczęściej jako [Hejduk, Grudzewski, Sankowska, Wańtuchowicz, 2009]:

- dyspozycja, czyli mentalny subiektywny stosunek (przekonanie) wobec drugiej strony (ocena, przewidywanie, oczekiwanie);

- decyzja, czyli intencja (zamiar) polegania na niej, przez co ufający staje się zależny od drugiej strony;

- zachowanie, które wypływa z aktu powierzenia się drugiej stronie.

Istotne zdaniem autora - dla literatury przedmiotu - poglądy prezentuje B. Dobiegała-Korona. Według niej zaufanie klientów do przedsiębiorstwa jest szczególnym rodzajem zaufania na rynku, a najważniejszą cechą relacji klient-firma jest asymetria. To zależność między słabym a mocnym, jednostką a organizacją, amatorem a profesjonalistą. Zaufanie zatem to subiektywne przekonanie, że przedsiębiorstwo nie wykorzysta swojej przewagi, aby nie działać na jego niekorzyść; zaufanie w końcu jest podstawowym czynnikiem współtworzenia wartości [Dobiegała-Korona, 2007, s. 22-23].

Współcześnie nabywca i konsument stał się najcenniejszym kapitałem przedsiębiorstwa, jest postrzegany jako partner firmy w procesie wytwarzania wartości. Dlatego też w problematyce rozważanej w niniejszym 
opracowaniu pojawia się kolejny istotny aspekt dotyczący klienta oraz jego znaczenia w warunkach dynamicznych i nieprzewidywalnych zmian zewnętrznego i wewnętrznego otoczenia. Wzrastająca złożoność warunków funkcjonowania na rynku, w tym szybko rosnąca liczba produktów i konkurentów, powoduje, że klient jest w centrum zainteresowania przedsiębiorstwa. Wiedza o kliencie, w tym znajomość jego potrzeb i preferowanych wartości, stała się niezwykle cenną umiejętnością w kreowaniu wartości przedsiębiorstwa. Prawdziwym wyzwaniem w Wieku Interaktywnym jest budowanie relacji z klientami i zarządzanie nimi w kierunku wzmocnienia więzi i zaufania pomiędzy klientami a organizacją. Chodzi tutaj o kształtowanie więzów oraz pomnażanie ich wartości dla konsumentów oraz przedsiębiorstw z pożytkiem dla tych pierwszych i jednocześnie zyskiem dla drugich [Newell, 2000, s. 23]. Budowa kapitału klienta przez wartość relacji wymaga tworzenia wąskich segmentów, wręcz indywidualnego traktowania potencjalnych konsumentów [Doyle, 2003, s. 104; Burnett, 2002, s. 20].

\section{SIECI HANDLOWE A ZAUFANIE KONSUMENTA - WYNIKI BADAŃ}

Tematem niniejszego artykułu jest zaufanie konsumenta na rynku marketów budowlanych, dlatego też celowe będzie zilustrowanie specyfiki ww. branży. Jednym z najważniejszych graczy na rynku dystrybucji materiałów budowlanych i dekoracyjnych są sieci marketów budowlanych należące przede wszystkim do międzynarodowych koncernów. W latach 2005-2013 zaobserwować można wzrost udziału tego typu sklepów z około $24 \%$ do prawie $40 \%$, kosztem hurtowni i składów budowlanych (spadek do 54\% z 67,5\%). Udział sklepów specjalistycznych utrzymuje się na stałym ponad 6\% poziomie. Na początku 2005 roku najliczniejszą siecią marketów budowlanych była Nomi, która posiadała 34 oddziały. Castorama miała 27 placówek, OBI - 23, Praktiker - 16, a Leroy-Merlin 14 sklepów. Obecnie wśród sieci marketów budowlanych dominuje Castorama należąca do grupy Kingfisher, Leroy Merlin (Groupe Adeo), a także OBI (Tengelmann Group). Razem ww. sieci handlowe mają ponad 3/4 udziału w rynku. 


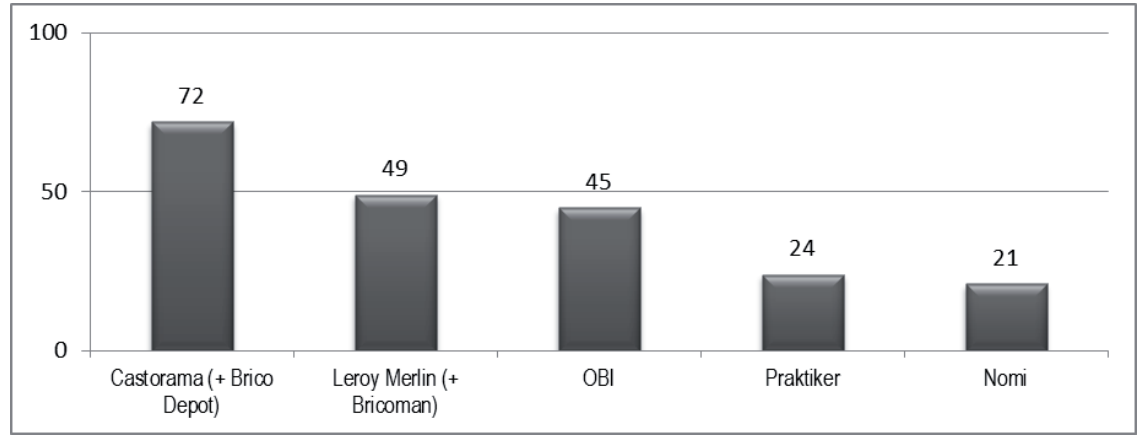

Rysunek 1. Liczba oddziałów sklepów wielkopowierzchniowych w Polsce (stan na 1.07.2014 r.)

Źródło: opracowanie własne.

Według danych ASM Centrum Badań i Analiz Rynku prawie co piąty market DIY w 2011 r. był zlokalizowany w miastach od 21 tys. do 50 tys. mieszkańców. Znaczący odsetek sklepów (prawie 23\%), ulokowany był w miejscowościach do 20 tys. mieszkańców. Rysunek 2 prezentuje lokalizację sklepów w poszczególnych województwach.

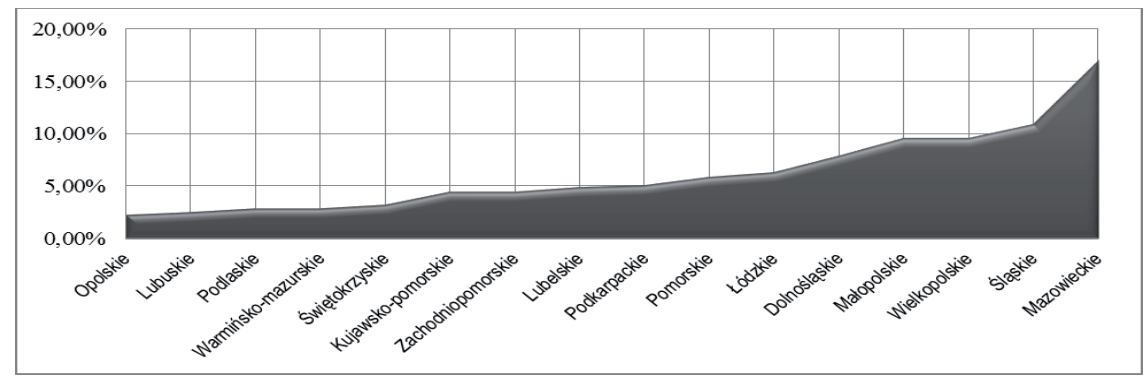

Rysunek 2. Lokalizacja punktów sprzedaży materiałów budowlanych wg województw

Źródło: IBP Research, http://ibpresearch.pl/rynek-dystrybucji-materialow-budowlanych-w-polsce, dostęp z dnia 02.07.2014.

Zakupy materiałów budowalnych i dekoracyjnych podlegają dużym wahaniom sezonowym, z nasileniem sprzedaży w okresie wiosenno-letnim. Kluczowe znaczenie dla popytu ma również pogoda, a załamanie sprzedaży występuje zazwyczaj w okresie zimowym. Nie bez znaczenia dla branży pozostaje kryzys na rynkach finansowych. W ciągu ostatnich dwóch 
lat sektor skurczył się o ponad 5 mld zł. Największe przyrosty sprzedaży (ilościowo i wartościowo) sieci handlowe osiągały w latach 2006-2008 oraz w 2011 roku. W 2012 roku sam rynek materiałów budowlanych wart był prawie 46400 mld zł, w tym rynek dystrybucji wyniósł 38400 mld zł. W latach 2012-2013 rynek dystrybucji zmniejszył się o prawie 13 p.p.

Podsumowując dotychczasowe rozważania, z dużym prawdopodobieństwem można wskazać na dalszy rozwój sieci handlowych, zaostrzenie konkurencji, rozwój technologii teleinformatycznych, magazynowych, transportowych, a także na zwiększenie intensywności kooperacji i umacniania więzi z partnerami [nt. rynku budowlanego patrz m.in. Zupok, 2014, s. 60-68; Zupok, 2015, s. 46-58].

Analizując sektor sprzedaży materiałów budowlanych i dekoracyjnych, wyróżnić można dwa rodzaje zaufania. $Z$ jednej strony istnieje zaufanie, którymi sieci handlowe są obdarzane przez dostawców (partnerów handlowych). Istnieje także zaufanie, jakim nabywca (konsument) obdarza sprzedającego. Niezbędna jest zatem umiejętność dokonania właściwej oceny wiarygodności podmiotów rynkowych i obdarzenie zaufaniem jedynie tych, które na to zaufanie zasługują. Konieczność budowania zaufania doprowadziła do powstania zbioru działań i metod, zwanego zarządzaniem zaufaniem. Owe działania i metody mają na celu przede wszystkim pomoc podmiotom w dokonywaniu ocen i decyzji, które będą rzutowały na obdarzenie innych zaufaniem oraz w budowaniu wiarygodności organizacji.

Badania przeprowadzono w drugim kwartale 2014 r. wśród 1140 nabywców materiałów budowlanych $\mathrm{w}$ tzw. kanale nowoczesnym $\mathrm{z}$ terenu całej Polski. Zostały one zrealizowane metodą sondażu z wykorzystaniem technik wywiadu kwestionariuszowego. Dane wykorzystane w opracowaniu stanowią część badań sektora marketów budowlanych.

Badana próba składała się w 73,9\% z mężczyzn; 45,7\% z nich było w wieku 30-39 lat, najliczniejszą grupę (62,7\%) stanowiły osoby z wykształceniem średnim i z dochodem na osobę w przedziale $801-1000$ zł $(35 \%)$.

Zdecydowana większość respondentów dokonuje zakupów w sklepach wielkopowierzchniowych (82\%). Klienci sklepów typu DIY to najczęściej osoby młode (56,5\%), z wyższym i średnim wykształceniem, mieszkańcy dużych miast oraz osoby o najwyższych dochodach ( $\mathrm{tj}$. od $800 \mathrm{zł}$ na osobę wzwyż). Połowa badanych deklaruje, że dokonuje zakupów w markecie średnio raz na dwa tygodnie (51\%). Co piąta osoba robi zakupy w tego rodzaju sklepie częściej niż raz w tygodniu. Co trzeci respondent korzysta z DIY raz w miesiącu lub rzadziej. Trzech na czterech badanych deklaruje, 
że robi zakupy w wielu marketach budowlanych, nie ograniczając się do jednego.

Nabywcy wybierają przede wszystkim Castoramę (406 badanych osób), a także Leroy Merlin i OBI (odpowiednio: 341 i 334 osoby). Rysunek 3 prezentuje szczegółowe dane. Warto dodać, iż co piąta osoba dokonuje zakupów poprzez sklep internetowy, głównie sieci Castorama i Leroy Merlin ${ }^{1}$.

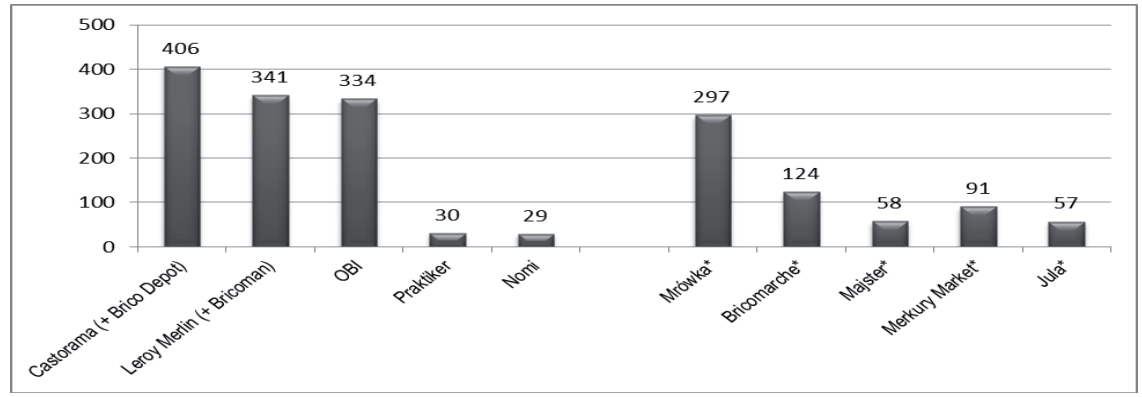

Rysunek 3. Najczęściej wybierane przez nabywców sieci marketów budowlanych Źródło: opracowanie własne.

Kolejny aspekt badań empirycznych dotyczył ważności wyodrębnionych determinantów kształtowania zaufania. Na podstawie uzyskanych wyników stwierdzono, że spełnienie oczekiwań klientów, dywersyfikacja asortymentu, doskonalenie ofert oraz edukacja klientów okazały się najważniejszymi czynnikami determinującymi zaufanie konsumenckie aktualnych i potencjalnych klientów (razem ponad 76\% wskazań). Pozostałe determinanty to: doskonalenie procesów rozumiane jako m.in. specjalna obsługa klientów, zmiany w wyposażeniu i infrastrukturze, informacja oraz sponsoring.

W trakcie badań poproszono respondentów o wskazanie preferowanych przez nich wartości w układzie: wartość podstawowa, wartość dodatkowa, wartość poszerzona o obsługę oraz wartość oparta na relacjach [Zupok, 2014, s. 66-67]. Tablica 1 prezentuje zbiorczo preferowane wartości oraz czynniki kształtujące, zdaniem respondentów, ich zaufanie do organizacji.

1 W czasie przeprowadzonych badań sklep internetowy posiadały następujące organizacje: Castorama, Leroy Merlin i Praktiker. Sieć marketów OBI uruchomiła e-sklep dopiero w pierwszym kwartale $2015 \mathrm{r}$. 
Tabela 1. Preferowane wartości dla klienta

\begin{tabular}{|c|c|c|c|c|}
\hline $\begin{array}{l}\text { Poziom } \\
\text { wartości }\end{array}$ & Elementy & Powód 1 & Powód 2 & Powód 3 \\
\hline \multirow{12}{*}{$\begin{array}{l}\text { Wartość } \\
\text { podstawowa }\end{array}$} & Szeroka oferta produktowa & $58,00 \%$ & $25,00 \%$ & $12,90 \%$ \\
\hline & Dostępność produktów & $20,50 \%$ & $33,00 \%$ & $34,70 \%$ \\
\hline & Poziom cen & $50,00 \%$ & $42,00 \%$ & $19,70 \%$ \\
\hline & Dogodne godziny otwarcia & $18,60 \%$ & $10,00 \%$ & $15,10 \%$ \\
\hline & $\begin{array}{l}\text { Dobra komunikacja z miastem/ } \\
\text { /drogami }\end{array}$ & $12,80 \%$ & $4,70 \%$ & $10,90 \%$ \\
\hline & Łatwość parkowania & $11,00 \%$ & $5,10 \%$ & $3,40 \%$ \\
\hline & Możliwość zakupów w niedzielę & $23,00 \%$ & $27,00 \%$ & $6,90 \%$ \\
\hline & Możliwość płacenia kartą & $13,00 \%$ & $4,60 \%$ & $8,00 \%$ \\
\hline & $\begin{array}{l}\text { Dostępna, fachowa i kompetentna } \\
\text { obsługa }\end{array}$ & $27,40 \%$ & $11,40 \%$ & $16,70 \%$ \\
\hline & Sąsiedztwo innych sklepów & $12,60 \%$ & $10,40 \%$ & $5,50 \%$ \\
\hline & Czyste toalety dla klientów & $3,80 \%$ & $5,30 \%$ & $6,00 \%$ \\
\hline & Łatwość załadunku towarów & $21,00 \%$ & $8,00 \%$ & $11,40 \%$ \\
\hline \multirow{4}{*}{$\begin{array}{l}\text { Wartość } \\
\text { dodatkowa }\end{array}$} & Możliwość negocjacji cen & $73,80 \%$ & $15,30 \%$ & $15,80 \%$ \\
\hline & Możliwość wypożyczenia narzędzi & $9,70 \%$ & $41,60 \%$ & $32,00 \%$ \\
\hline & Wymiana produktów uszkodzonych 1:1 & $43,80 \%$ & $32,40 \%$ & $7,50 \%$ \\
\hline & $\begin{array}{l}\text { Możliwość sprowadzenia produktów na } \\
\text { zamówienie }\end{array}$ & $34,70 \%$ & $16,60 \%$ & $20,00 \%$ \\
\hline \multirow{4}{*}{$\begin{array}{l}\text { Wartość } \\
\text { poszerzona } \\
\text { o obsługę }\end{array}$} & $\begin{array}{l}\text { Fachowe doradztwo techniczne i asor- } \\
\text { tymentowe }\end{array}$ & $66,60 \%$ & $42,90 \%$ & $40,90 \%$ \\
\hline & $\begin{array}{l}\text { Bezpłatny transport i pomoc wniesieniu } \\
\text { produktu }\end{array}$ & $15,90 \%$ & $52,90 \%$ & $19,30 \%$ \\
\hline & Projektowanie & $28,20 \%$ & $16,90 \%$ & $8,90 \%$ \\
\hline & Programy lojalnościowe & $13,00 \%$ & $9,20 \%$ & $23,60 \%$ \\
\hline \multirow{3}{*}{$\begin{array}{l}\text { Wartość } \\
\text { oparta na } \\
\text { relacjach }\end{array}$} & Indywidualizacja oferty & $26,50 \%$ & $34,10 \%$ & $13,90 \%$ \\
\hline & Indywidualizacja cen & $31,05 \%$ & $21,90 \%$ & $23,90 \%$ \\
\hline & Personalizacja w procesie komunikacji & $45,50 \%$ & $20,20 \%$ & $16,90 \%$ \\
\hline
\end{tabular}

Źródło: opracowanie własne. 


\section{PODSUMOWANIE}

Wraz ze wzrostem niepewności i ryzyka w zarządzaniu współczesnymi organizacjami nastąpił wzrost zainteresowania tzw. miękkimi czynnikami, do których zalicza się m.in. zaufanie. Przedstawiane w opracowaniu rozważania, choć poparte jedynie ogólnymi wynikami badań, wydają się potwierdzać ważność tego zjawiska z punktu widzenia budowy wartości przedsiębiorstwa.

Z przeprowadzonych badań wynika, że pełna świadomość potrzeb klienta, wiedza klienta na temat oferowanych mu produktów i usług, symetria relacji klient - organizacja, autentyczne zaangażowanie i uczciwość dostawcy. Aby skutecznie kreować zaufanie, za bezwzględny piorytet należy uznać maksymalizowanie wartości życiowej klienta. Oznacza to, że produkty i usługi muszą być podporządkowane długoterminowym relacjom z klientami lub ich wąskimi segmentami, opartymi na zaufaniu obu stron.

\section{LITERATURA}

Boon S. D., Holmes J. G. (1991), The dynamics of Interpersonal Trust: Resolving Uncertainly in the Face of Risk, w: Cooperation and Prosocial Behavior, Hinde R. A., Groebel J. (ed.), Cambridge University Press, Cambridge.

Brogan Ch., Smith J. (2011), Zaufanie 2.0. Jak wywierać wpływ, zdobyć lojalność klientów i kreować markę, One Press, Gliwice.

Bruni L., Sugden R. (2000), Moral Canals: Trust and Social Capital In the Work of Hume, Smith and Genovesi, Economics and Philosophy, nr 16.

Burnett K. (2002), Relacje z kluczowymi klientami. Analiza i zarządzanie, Oficyna Ekonomiczna, Kraków.

Bylok F. (2012), Budowa zaufania konsumenckiego jako czynnik determinujący sukces przedsiębiorstwa w warunkach kryzysu, Zarządzanie i Finanse, t. 4, nr 1/2012, Wydział Zarządzania - Uniwersytet Gdański.

Dobiegała-Korona B., Polskie firmy ucza się orientacji na klienta, Harvard Business Review, grudzień 2010-styczeń 2011.

Dobiegała-Korona B., Herman A. (2006), Współczesne źródła wartości przedsiębiorstwa, Difin, Warszawa.

Dobiegała-Korona B. (2007), Zaufanie klienta, Kwartalnik Nauk o Przedsiębiorstwie, 2/2007 (3).

Doyle P. (2003), Marketing wartości, Wydawnictwo Felberg SJA, Warszawa. 
Fukuyama F. (1997), Zaufanie. Kapital społeczny a droga do dobrobytu, PWN, Warszawa-Wrocław.

Giddens A. (2006), Socjologia, PWN, Warszawa.

Grudzewski W. M., Hejduk I. K., Sankowska A., Wańtuchowicz M. (2009), Zarzadzanie zaufaniem w przedsiębiorstwie: koncepcja, narzędzia, zastosowanie, Oficyna Wolters Kluwer Bussines, Kraków.

Grudzewski W. M., Hejduk I. K., Sankowska A., Wańtuchowicz M. (2007), Zarzadzanie zaufaniem $w$ organizacjach wirtualnych, Difin, Warszawa.

Grudzewski W. M., Hejduk I. K. (2007), Zaufanie w kreowaniu strategii przedsiębiorstwa, Kwartalnik Nauk o Przedsiębiorstwie, 2/2007 (3).

Hejduk I. K., Grudzewski W. M., Sankowska A., Wańtuchowicz M. (2009), Znaczenie zaufania $i$ zarzadzania zaufaniem $w$ opinii przedsiębiorstw, E-mentor, $\operatorname{nr} 5$ (32)/2009, http://www.e-mentor.edu.pl/artykul/index/numer/32/ id/696, dostęp: 31.12.2014.

Inglehart R. (1997), Modernization and postmodernization. Cultural, Economic and political change in 43 societies, Princeton, NJ: Princeton University Press.

Koler Ph., Caslione J. A. (2009), Chaos. Zarzadzanie i marketing w erze turbulencji, Wyd. MT Biznes, Warszawa.

Mruk H., Stępień B. (2013), Tworzenie wartości dla klienta z perspektywy konsumentów i przedsiębiorstw, PWE, Warszawa.

Newell F. (2000), Loyalty.com. Customer Relationship Management in the New Era of Internet Marketing, McGraw-Hill Companies, New York.

Neumann M. M. (2006), Konsumentenvertrauen. Messung, Determinanten und Konsequenzen, Deutscher Universitats - Verlag, Wiesbaden.

Sankowska A. (2011), Wpływ zaufania na zarzadzanie przedsiębiorstwem. Perspektywa wewnątrzorganizacyjna, Difin, Warszawa.

Sztompka P. (2007), Zaufanie. Fundament społeczeństwa, Wyd. Znak, Kraków.

Young L., Albaum G. (2003), Measurement of Trust: in Salesperson-Customer Relatinship in Direct Selling, Journal of Personal Selling and Sales Management nr 23, vol. 3 .

Zak P. J., Knack S. (2001), Trust and growth, The Economic Journal, nr 111.

Zupok S. (2014), Zachowania nabywcze konsumentów na krajowym rynku materiałów budowlanych, Ekonomika i Organizacja Przedsiębiorstw, nr 11 (778), listopad 2014.

Zupok S. (2015), Kreowanie wartości dla klienta, Ekonomika i Organizacja Przedsiębiorstw, nr 3 (782), marzec 2015. 


\title{
CUSTOMER TRUST AS A KEY FACTOR IN BUILDING VALUE IN TYPE DIY RETAIL ENTERPRISES
}

\begin{abstract}
The subject under discussion in this paper is the customer's trust and its impact on creating value by companies suppling building materials. Studies have shown that partnerships between customers and companies in the process of cocreating value must be built on involvement of both sides. It has been proven that trust in the turbulent environment is an important factor for market success of DIY networks.
\end{abstract}

Keywords: confidence, client, company values, DIY. 